\title{
Litter fall and decomposition of mangrove species Avicennia marina and Rhizophora mucronata in Maputo Bay, Mozambique
}

\author{
Stela M.C. Fernando and Salomão O. Bandeira \\ Department of Biological Sciences, Eduardo Mondlane University, PO Box 257, Maputo, Mozambique
}

Keywords: Litter fall, leaf decomposition, sub-tropical, southern Mozambique.

\begin{abstract}
Litter fall and decomposition of mangrove leaves were compared for different seasons, species (Avicennia marina and Rhizophora mucronata) and sites in southern Mozambique. Mangrove leaf litter fall and decomposition was estimated using small mesh collecting-baskets and litter bags respectively in 2006 and 2007 at two sites of Maputo Bay: an urban dwarf mangrove at Costa do Sol (Maputo City) and a rural well-developed mangrove at Saco (Inhaca Island). A. marina at Saco produced more litter (dry season $10.6 \mathrm{~g} \mathrm{~m}^{-2}$ and wet season $14.2 \mathrm{~g} \mathrm{~m}^{-2}$ ) than $R$. mucronata (dry season $4.6 \mathrm{~g} \mathrm{~m}^{-2}$ and wet season $14.1 \mathrm{~g} \mathrm{~m}^{-2}$ ), and leaves contributed more to total litter fall in the dry season (February/March) compared with the wet season (September/October) for both species. Decomposition by means of loss of ash free dry weight (AFDW) from leaves maintained in the subtidal was best described by double exponential models which showed loss rates of leaves along the time. Field experiments at Saco showed that submerged leaves of $A$. marina decomposed faster than $R$. mucronata. For $A$. marina, the average time required to lose half of the initial AFDW $\left(\mathrm{t}_{0,5}\right)$ was 96 days and 78 days for the dry and wet season respectively, whereas for $R$. mucronata leaves it took 151 days in the dry and 476 days in the wet season. At Costa do Sol, A. marina leaves took 171 and 48 days for the dry and wet seasons respectively to lose half AFDW; whereas $R$. mucronata took 98 days in the dry and 25 days in the wet season. The results showed that breakdown of leaf litter was season and species dependent. Litter decomposition in the wet season was faster than the dry season and A. marina had the fastest decomposition rates, appearing to act as a principle pioneer species for enrichment of the fringing mangrove habitats of sub-tropical eastern Africa.
\end{abstract}

\section{INTRODUCTION}

Mangrove forests are highly productive ecosystems (Boto et al., 1984; Woodroffe, 1985; Woodroffe et al., 1988; Nybakken, 1993) and this productivity is mainly attributed to the high degradation of litter fall and efficient recycling of nutrients (Bosire et al., 2005; Morrisey et al., 2007). Methods of directly measuring primary productivity in mangrove ecosystems are technically difficult but litter production has been widely used as a measure of productivity as this is one of the important components of productivity, especially in view of its nutrient contribution to the estuarine systems (Woodroffe et al., 
1988; Mall et al., 1991; Chale, 1996; Morrisey et al., 2007). Thus, quantifying litter fall and decomposition becomes essential to assess the productivity of the ecosystem as a whole (Wafar et al., 1997).

Litter production and fall is accepted as the main pathway to enrich the ecosystem with nutrients (Tam et al. 1998) but it tends to vary with geographic location (Twilley, 1985; Woodroffe et al. 1988) and seasons (Bosire et al., 2005). In some locations litter production and fall occurs throughout the year with peak fall in summer rainy seasons as documented by Tam et al. (1998) in China.

The decomposition of plant material is the process in which organic substances are physically broken down and converted into simple chemical substances, resulting in the production of carbon dioxide, water and released energy (Chapman, 1986). Decomposition rate can be summarized as the time a body spends to lose mass to half of its initial value or half life (Hogarth, 1999). Decomposition of organic substances and recycling of detritus have great importance in nutrient release from ground organic substance (Raffaelli \& Hawkins, 1996), enabling the substance to become available for new growth of plants (Chapman, 1986; Hogarth, 1999; Shunula \& Whittick, 2001).

Mangrove leaf litter degradation depends mainly on seasonal variability and on the degree and frequency of tidal inundation (Twilley, 1985; Wafar et al., 1997, Dick \& Osunkoya 2000, Bosire et al., 2005). The objective of this study was to document mangrove litter fall and decomposition rates in two contrasting mangrove habitats: a welldeveloped mangrove habitat in a rural setting and a dwarf mangrove in an urban setting.

\section{MATERIALS AND METHDOS}

\section{Study area}

This study was undertaken in two distinct mangrove habitats, a well developed mangrove in a rural setting (Inhaca Island) and a dwarf mangrove in an urban setting (Costa do Sol). These two locations occur in Maputo Bay, southern Mozambique (Fig. 1) and there are no tidal differences between the two sites as they are exposed to the same bi-diurnal tidal regimes, with the highest spring tide amplitude reaching close to $4 \mathrm{~m}$ (Mundlovo, 2006)). The study was undertaken during the two main seasons: wet (September and October) and dry (February and March). Maputo Bay has an area of $960 \mathrm{~km}^{2}$ (Afonso, 2001) and five main rivers, namely the Incomati, Maputo, Matola, Tembe and Umbeluzi which empty into Maputo Bay. The climate is subtropical, with a rainy warmer season from October to February, and a dry, cooler season from March to September (Mundlovo, 2006). According to data collected from Instituto Nacional de Meteorologia from 1998 to 2008 , precipitation varies from the extremes $34.7-211.9 \mathrm{~mm}$ a month in the wet season and $7.7-77.3 \mathrm{~mm}$ in the dry.

The dwarf mangrove forest at Costa do Sol is subjected to anthropogenic impacts such as land reclamation for building construction (Saket \& Matusse, 1994; Barbosa et al., 2001). Within this approximately $1.5 \mathrm{sq}$. km forest, $A$. marina is the dominant species and is known to tolerate high salinities (Hogarth, 1999; Yong Ye et al., 2005; Beentje \& Bandeira 2007). The average height of this mangrove species is 1.5 metres, and the dwarf appearance is thought to be due to high salinity, up to 45.9 ppt (see Simango, 2007). The mangroves at Saco occur in the southern bay of Inhaca Island (Fig. 1) which is protected from wind and strong waves. There is no river on the island but some fresh groundwater from inland reaches the mangroves (Kalk, 1995). These mangroves are part of the forestry reserve of Inhaca Island (Kalk, 1995) that has been protected for around 40 years and are considered fully-developed, and including a range of species including $A$. marina and $R$. mucronata. 


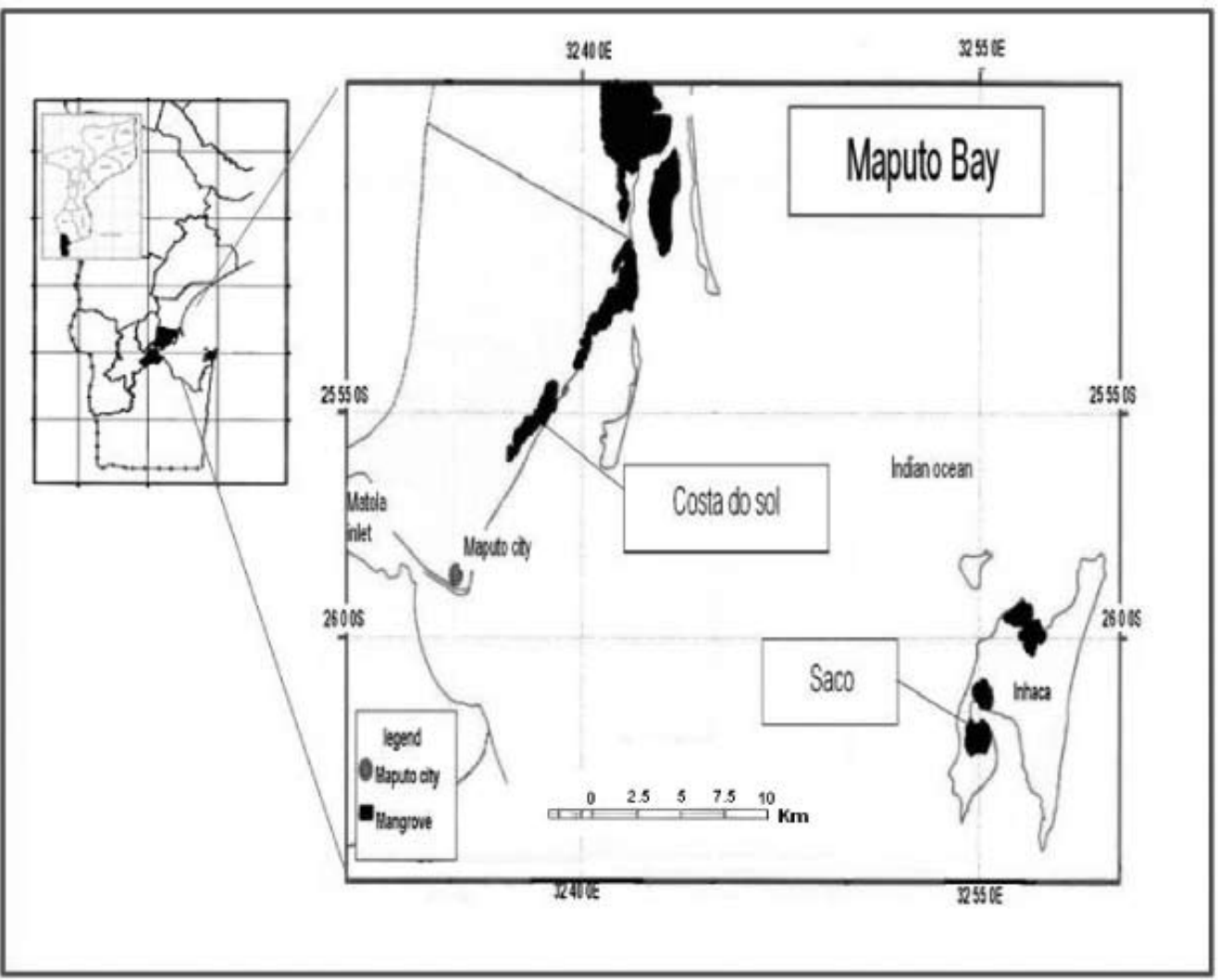

Fig. 1. Map depicting the study areas in southern Mozambique

\section{Litter fall}

For the determination of daily rates of litter fall, bags with an area of $0.25 \mathrm{~m}^{2}$ and mesh of $1 \mathrm{~mm}$ (see Ellis \& Bell, 2004) were tied to branches up to $2 \mathrm{~m}$ above the forest floor, in order to prevent them from getting wet during high tide (following Tam et al., 1998). Bags were kept at least $10 \mathrm{~m}$ apart from each other. Five replicate bags were tied in the branches of the trees in the $A$. marina and $R$. mucronata zones. The samples were harvested biweekly (14, 28, 42 and 56 days period), covering two months for each season (dry and wet). The harvested litter was immediately placed in plastic bags and returned to the laboratory where it was identified and divided into leaf, branch and fruit categories (following Tam et al., 1998; Ellis \& Bell, 2004). The litter was dried in aluminium paper at a temperature of $100^{\circ} \mathrm{C}$ for $72 \mathrm{~h}$ and subsequently weighed as dry weight (Woodroffe, 1985; Ellis \& Bell, 2004). This experiment was carried out only at Saco (normal mangrove) because at Costa do Sol (the dwarf mangrove stand) the plants were shorter than $1.5 \mathrm{~m}$ resulting in the leaf litter washing away during spring high tides.

\section{Decomposition}

In order to estimate the rate of mangrove breakdown, litter bags were used for both Rhizophora mucronata and Avicennia marina at both study sites. The leaves used 
were senescent (yellowish in colour) either freshly fallen or easily hand picked from the trees and surrounding area (see Van Der Valk \& Attwill, 1984; Ashton et al., 1999). These are normally the majority of the leaves on the forest floor and they have already started their decomposition (Ashton et al., 1999; Bosire et al. 2005). These leaves were air dried for $24 \mathrm{~h}$ to remove surface water, and then $28 \mathrm{~g}$ of each species was placed into 15 x $15 \times 25 \mathrm{~cm}$ plastic bags with a mesh size of $1 \mathrm{~mm}^{2}$ (Ashton et al., 1999). The mesh bags were securely tied to aerial roots so that they lay flat on the sediment. Eight bags for each species were removed from each site at each of 14, 28, 42 and 56 days, covering two months per season (dry and wet). In total 64 litter bags were placed per season, at the beginning of the decomposition experiment to ensure independence of sampling (Underwood, 1997). These bags were returned to the laboratory where they were gently washed in a sieve to remove sediment. The resulting litter was oven dried to constant mass at $100^{\circ} \mathrm{C}$ for $72 \mathrm{~h}$ and the final dry mass recorded (Ellis \& Bell, 2004).

\section{Data analyses}

Differences in litter production between the dry and wet season for the two mangrove species (A. marina and $R$. mucronata) were tested using factorial ANOVA. The relationship between the percentage dry biomass of remaining mass in litter bags and species sampling time, at both sites, best fitted a negative single exponential model (Ref): $X_{t}=X_{o} e^{-K t}$. Where $X_{t}$ is the percentage of the initial material $\mathrm{X}_{\mathrm{o}}$ remaining after time $t$ (days) and $\mathrm{K}$ is a decay coefficient $\left(\mathrm{d}^{-1}\right)$. The times required for the decomposition of half the initial material $\left(\mathrm{t}_{50}\right)$ were determined $(\mathrm{t}=$ $\ln 2 / K)$. The exponential curves obtained were converted to straight lines $\left(\log _{10}\right)$ and ANOVA tests were carried out for every combination of litter bags. All statistical analyses were performed using the "Statistica" program. A significance level of $p=0.05$ was accepted.

\section{RESULTS}

\section{Litter fall}

Litter production and fall were observed throughout the year at Saco and there was a distinct seasonal pattern, with peak fall during summer rains and little fall in winter. Leaves were the dominant form of litter (Table 1) and contributed more to total litter in the dry season compared with the wet season for the two species. Twig fall was almost continuous representing a small percentage of the total litter fall (up to $20 \%$ of dry weight). The fall of reproductive parts (fruits and flowers) was strongly seasonal as this was higher during the wet season. Reproductive parts weighed more than the other litter components. $R$. mucronata propagules contributed $47.7 \%$ to total litter fall in the wet season. Observations and herbarium records from Inhaca Island have shown that $R$. mucronata flowering occurs in the periods of October-December and fruiting in December-May and, A. marina flowering occurs in September-December and fruiting in December-May. There was no significant difference in total litter production between the wet and dry season $(\mathrm{P}>0.05)$ although it appeared that total litter production was greater for A. marina (10.64 $\mathrm{g} \mathrm{m}^{-2}$ in dry season and $14.18 \mathrm{~g} \mathrm{~m}^{-2}$ in wet season) compared with $R$. mucronata $\left(4.64 \mathrm{~g} \mathrm{~m}^{-2}\right.$ in dry and $14.11 \mathrm{~g} \mathrm{~m}^{-2}$ in wet season).

\section{Decomposition}

When leaves fall on the sediment, decay initiates and rapid weight loss occurs. At Costa do Sol in the wet season, the first 28 days resulted in $50 \%$ of the initial dry weight lost in $R$. mucronata while in A. marina the same percentage loss occurred over 56 days (Fig. 2). At the Saco mangroves of Inhaca Island, leaves only decomposed up to a third of the initial dry weight during all field measurements (eight weeks) (Fig. 2). The decomposition rate during the dry season was much slower in these two study areas. 
Table 1. Percentage contribution of plant material to litter fall at Inhaca Island (Saco) for $A$. marina (Am) and R. mucronata (Rm)

\begin{tabular}{|c|c|c|c|c|}
\hline & Species & Season & Mean \pm S.D. & $\%$ \\
\hline \multirow[t]{4}{*}{ Leaves } & \multirow[t]{2}{*}{$\mathrm{Am}$} & Wet & $24.91 \pm 22.65$ & 76.5 \\
\hline & & Dry & $14.99 \pm 3.62$ & 85.9 \\
\hline & \multirow[t]{2}{*}{$\mathrm{Rm}$} & Wet & $17.22 \pm 7.42$ & 34.9 \\
\hline & & Dry & $31.24 \pm 14.20$ & 79.4 \\
\hline \multirow[t]{4}{*}{ Twigs } & \multirow[t]{2}{*}{$\mathrm{Am}$} & Wet & $5.78 \pm 4.00$ & 12.8 \\
\hline & & Dry & $1.44 \pm 1.99$ & 13.0 \\
\hline & \multirow[t]{2}{*}{$\mathrm{Rm}$} & Wet & $0.55 \pm 0.63$ & 1.1 \\
\hline & & Dry & $5.93 \pm 11.76$ & 20.4 \\
\hline \multirow[t]{4}{*}{ Inflorescence } & \multirow[t]{2}{*}{$\mathrm{Am}$} & Wet & $1.92 \pm 3.39$ & 0.3 \\
\hline & & Dry & $0 \pm 0$ & 0 \\
\hline & \multirow[t]{2}{*}{$\mathrm{Rm}$} & Wet & $3.98 \pm 2.49$ & 8.2 \\
\hline & & Dry & $0.04 \pm 0.07$ & 0 \\
\hline \multirow[t]{4}{*}{ Propagules } & \multirow[t]{2}{*}{$\mathrm{Am}$} & Wet & $5.24 \pm 9.29$ & 10.4 \\
\hline & & Dry & $0 \pm 0$ & 0 \\
\hline & \multirow[t]{2}{*}{$\mathrm{Rm}$} & Wet & $23.54 \pm 47.08$ & 47.7 \\
\hline & & Dry & $0 \pm 0$ & 0 \\
\hline \multirow[t]{4}{*}{ Fruit } & \multirow[t]{2}{*}{$\mathrm{Am}$} & Wet & $0 \pm 0$ & 0 \\
\hline & & Dry & $0.04 \pm 0.08$ & 1.1 \\
\hline & \multirow[t]{2}{*}{$\mathrm{Rm}$} & Wet & $4.10 \pm 8.21$ & 8.3 \\
\hline & & Dry & $0.03 \pm 0.05$ & 0.3 \\
\hline \multirow[t]{4}{*}{ Total } & \multirow[t]{2}{*}{$\mathrm{Am}$} & Wet & $37.86 \pm 18.49$ & 100 \\
\hline & & Dry & $16.47 \pm 3.01$ & 100 \\
\hline & \multirow[t]{2}{*}{$\mathrm{Rm}$} & Wet & $49.40 \pm 59.00$ & 100 \\
\hline & & Dry & $37.23 \pm 4.82$ & 100 \\
\hline
\end{tabular}

The times required to lose half of the initial AFDW $\left(\mathrm{t}_{0,5}\right)$ of periodically submerged leaves at the Saco mangrove were 96 days (in the dry season) and 78 days (during the wet season) for A. marina and 151 days (dry season) and 476 days (wet season) for $R$. mucronata. While at Costa do Sol this was 171 days (dry season) and 48 days (wet season) for $A$. marina and 98 days (dry season) and 25 days (wet season) for $R$. mucronata. There was no significant difference in decomposition rates of mangrove leaves in the two study areas. Analysis of variance showed that there were significant differences in percentage dry mass remaining between sites $(\mathrm{P}<0.05)$, season ( $\mathrm{P}$ $<0.05)$ and species $(\mathrm{P}<0.05)$.

\section{DISCUSSION AND CONCLUSION}

\section{Litter fall}

Litter fall could not be measured at Costa do Sol because of tidal flooding relative to height of branches, however, observations indicated that litter fall rates were lower in these dwarf or stunted mangroves compared to the fullydeveloped mangroves of Saco at Inhaca Island. Mangroves in New Zealand as documented by Woodroffe (1985) and Morrisey at al. (2007) recorded lower litter fall from stunted mangroves. At Costa do Sol, the dwarf plants had a small diameter, average height up to $1.5 \mathrm{~m}$ and low biomass (Amade, 2006), contributing to 


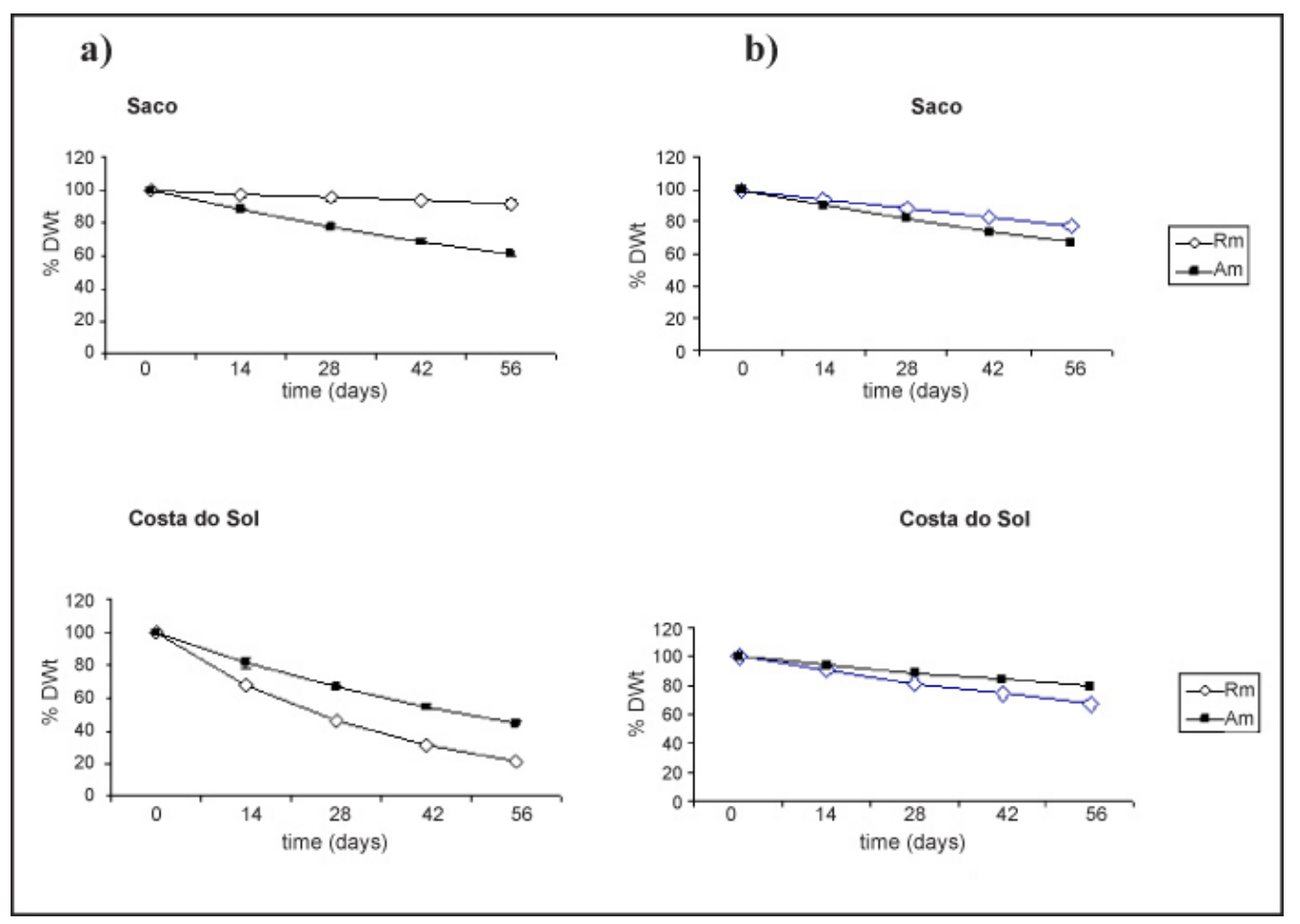

Fig. 2. Change in percentage dry weight of $A$. marina and $R$. mucronata in the wet season (a) and dry season (b)

a generally low productivity. Dwarf mangroves occur as a result of high salinities associated with desiccation due to fewer inundation periods (mainly restricted to spring tides) as observed in other stunted mangrove areas from Hong Kong (Yong Ye et al., 2005). This stress reduces seed establishment, and consequently impacts on plant development (Yong Ye et al., 2005).

The contribution of leaf fall to total litter was negatively related to that of the reproductive materials as the peak production of the reproductive materials occurred when leaf litter production was minimum (and vice versa). $R$. mucronata flowering occurs during January-March, June-August, OctoberDecember and fruiting in January-March, July-August, November-December (Kalk, 1995; Beentje \& Bandeira, 2007).

Studies of R. mucronata litter fall carried out in India revealed that twig fall was almost continuous but rarely exceeded a few percent (up to 20\%) of total litter fall (Wafar et al, 1997). Fall of flowers and fruit was confined to the wet season, and their contribution to total litter fall was quite substantial as observed elsewhere (Wafar et al., 1997; Hegazy, 1998). High temperature, longer duration of light, higher evapo-transpiration rates and more flushing by fresh water during summer months appears to be among the factors responsible for this high litter fall (Tam et al., 1998).

Despite mangroves being found only in tropical areas with similar environmental conditions, patterns of litter fall per square meter vary. This study showed different results, $38.8-51.8$ tones $\mathrm{ha}^{-1}$ year $^{-1}$ for $A$. marina and 16.9-51.5 tones ha $^{-1}$ year ${ }^{-1}$ for $R$. mucronata. In India litter fall was 10.2-11.8 tones ha ${ }^{-1}$ year ${ }^{-1}$ for Avicennia and Rhizophora respectively (Wafar et al., 1997). This difference may be due to age and height of trees and type of forest associated with the kind of mangrove forest such as the fringing river estuary or deltaic type. 
Table 2. Decay constant (Kd) and calculated half lives (t50) of $R$. mucronata and A. marina at Costa do Sol and Inhaca during the dry and wet season

\begin{tabular}{lcccr}
\hline Site & Litter type & Season & Kd $\left(\mathbf{d a y}^{-1}\right)$ & $\mathbf{t}_{\mathbf{5 0}}$ \\
\hline \multirow{2}{*}{ Costa do Sol } & A. marina & Dry & 0.004 & 171 \\
& & Wet & 0.014 & 48 \\
& R. mucronata & Dry & 0.007 & 98 \\
& & Wet & 0.028 & 25 \\
\hline \multirow{2}{*}{ Saco (Inhaca) } & \multirow{2}{*}{ A. marina } & Dry & 0.007 & 96 \\
& & Wet & 0.009 & 78 \\
& R. mucronata & Dry & 0.005 & 151 \\
& & Wet & 0.002 & 476 \\
\hline
\end{tabular}

\section{Decomposition}

Studies have shown that the decomposition rate of leaves was higher in the subtidal compared with the intertidal region and during the rainy season compared to the dry season, because water soaking causes leaching of labile materials (Robertson, 1988; Dick \& Osunkoya, 2000). In addition, higher temperatures of the wet season might enhance microbial activity, increase nutrient content of litter and accelerate decomposition rates (Tam et al., 1990). Similarly, Wafar et al. (1997) who undertook decomposition rate studies in India, found that the wet season resulted in rapid leaching. This study found the highest $t_{50}$ (half life) value for $R$. mucronata in the wet season at Saco, Inhaca, for the well-developed mangrove. $A$. marina leaves decomposed more rapidly than $R$. mucronata for both seasons at Inhaca. This was ascribed to differences in leaf morphology, texture and composition. According to Alongi et al. (2000) differences in leaf quality are known to affect decomposition rates as leaf tannin concentration and the nutritional value may vary. High tannin concentrations are known to be averse to detritivores and inhibit microbial activity (Van Der Valk \& Attwill, 1984; Robertson, 1988; Shunula and Whittick, 2001). Differences in litter tannin content might contribute to differences in mangrove leaf decomposition rate as microbial colonization of $R$. mucronata leaf litter appeared to occur after the tannin content of decomposing leaves dropped to a lower level (Tam et al., 1998; Ellison \& Farnsworth, 1997). At Costa do Sol, R. mucronata had lower decomposition than those documented elsewhere for Rhizophoraceae mangrove species (Ashton et al., 1999; Alongi, et al., 2000; Bosire et al., 2005). Few species of $R$. mucronata occurred at the dwarf mangrove site and the few leaves available to test decomposition might have already been leached, but further efforts are needed to measure the decomposition rates of $R$. mucronata from a stunted type of mangrove forest.

An overview of decay constant values $\left(\mathrm{K}_{\mathrm{d}}\right)$ for mangrove leaf litter reported in the literature is presented in Table 3 . Generally decay rates are seen to be affected by temperature, substrate characteristics and geographical regions (Woodroffe, 1985; Ellison and Farnsworth, 1997; Tam et al., 1998). The comparatively higher decomposition rates encountered at Saco de Inhaca could be due to the existence of high clay content in the substrate with a higher water retention capacity and higher organic matter percentage as documented by de Boer (2000). Larger macrofauna densities at Inhaca (Guerreiro et al., 1996) and the existence of a true mangrove forest compared to dwarf stands at Costa do Sol may have also prompted this difference in decomposition rate. The constants of decay observed in the study were relatively lower in relation to the studies in Kenya (Bosire 
Table 3. Overview of decay constant values $\left(K_{d}\right)$ for mangrove leaf litter reported in the literature, arranged from low to high rates of decomposition

\begin{tabular}{llcl}
\hline Litter type & Remarks & $\mathbf{K}_{\mathbf{d}}\left(\mathbf{d a y}^{-1}\right)$ & Source \\
\hline Avicennia marina & Dry season (Costa do Sol) & 0.004 & Present study \\
Avicennia marina & Dry season (Saco) & 0.007 & Present study \\
Avicennia marina & Wet season (Saco) & 0.009 & Present study \\
Avicennia marina & & $0.012-0.021$ & Tam et al. (1998) \\
Avicennia marina & Winter & 0.0126 & Tam et al. (1990) \\
Avicennia marina & Wet season (Costa do Sol) & 0.014 & Present study \\
Avicennia marina & & 0.063 & Robertson (1988) \\
Rhizophora mucronata & Wet season (Saco) & 0.002 & Present study \\
Rhizophora mucronata & Dry season (Saco) & 0.005 & Present study \\
Rhizophora mucronata & Cleared forest (Malaysia) & 0.0057 & Ashton et al. (1999) \\
Rhizophora mucronata & Dry season (Costa do Sol) & 0.007 & Present study \\
Rhizophora mucronata & Dry season (bare treatment) (Kenya) & 0.01 & Bosire et al. (2005) \\
Rhizophora mucronata & Virgin reserve & 0.0204 & Ashton et al. (1999) \\
Rhizophora mucronata & Wet season (Costa do Sol) & 0.028 & Present study \\
Rhizophora mucronata & Wet season (bare treatment) & 0.03 & Bosire et al. (2005) \\
Rhizophora mucronata & Dry season (natural treatment) & 0.18 & Bosire et al. (2005) \\
Rhizophora mucronata & Wet season (natural treatment) & 0.41 & Bosire et al. (2005) \\
\hline
\end{tabular}

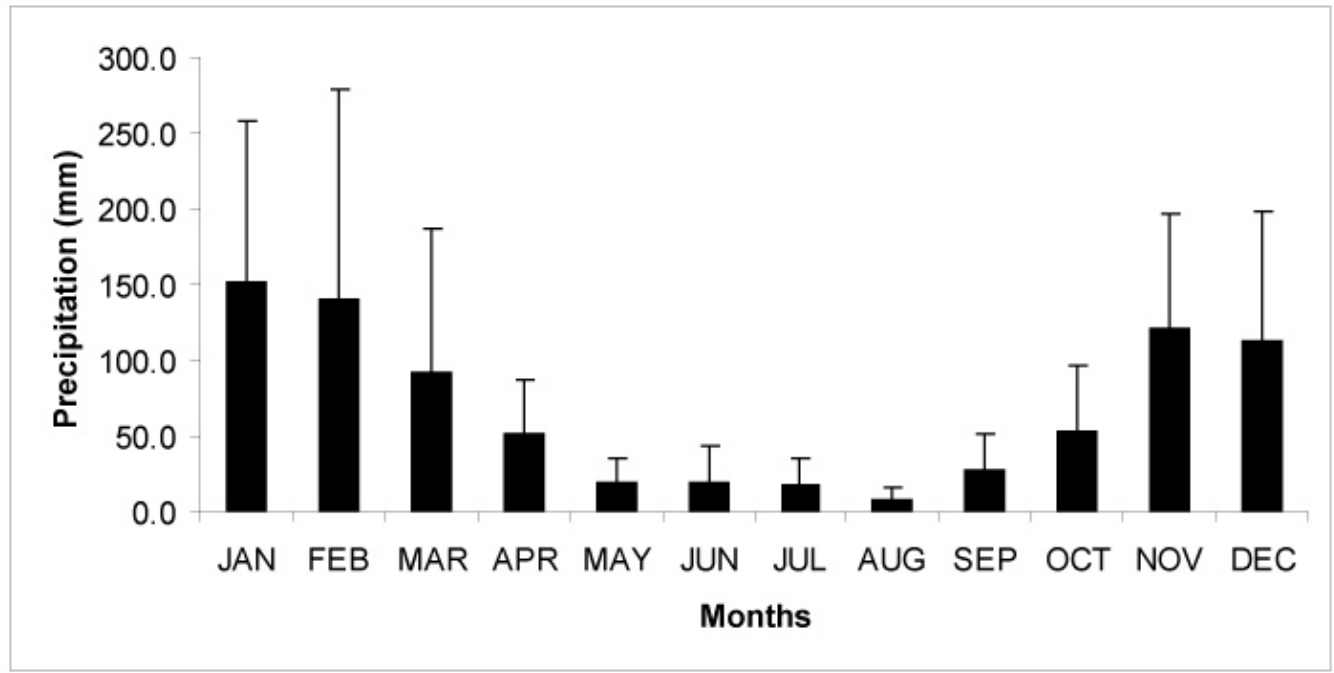

Fig. 3. Mean precipitation for a 10 year period (1998 to 2008) in Maputo Bay

et al., 2005) and Malaysia (Ashton et al., 1999), possibly due to different conditions in the field. In Kenya the total annual precipitation values $(1,000-1,600 \mathrm{~mm})$ were very high as the rainy season extended from April to August and from
October to the November months (Bosire et al., 2003) contrary to Maputo Bay where the annual precipitation ranged lower (360-1,000 $\mathrm{mm})$ as shown by a 10 year meteorological dataset (Fig. 3). Areas with high precipitation, 
mainly along the equator (such as Kenya) have high decomposition rates compared to areas further away even though they are subjected to similar tidal regimes.

To conclude, litter fall, which is seasonally and geographically dependent, appears to be the first to establish itself or the main 'pioneer' species to enriching the mangrove habitats in southern Mozambique. In the wet season the contributions of reproductive parts were higher than in the dry season but leaves were always present in litter fall. A. marina decomposed more rapidly than $R$. mucronata due to morphophysiological characteristics. Further studies are needed to understand the fate of the mangrove decomposition matter and existing connectivity with and transport into the adjacent shallow habitats such as seagrass beds and coral reefs.

Acknowledgements - The authors thank PUMPSEA and TRANSMAP European Union and MASMA projects for financial support. We acknowledge Prof. Janine Adams (Nelson Mandela Metropolitan University) for reviewing this paper. Votes of thanks are extended to the Marine Biological Station at Inhaca for logistical support; Mizeque Mafambissa for help at the early stage of this study and Estação Nhaca was instrumental during field work.

\section{REFERENCES}

Afonso, C.M.L. (2001). Aspectos da pesca e da biologia de Penaeus monodon Fabricius, 1798 e Penaeus semisulcatus de Haan, 1844 na pescaria artesanal de camarão da baía de Maputo, Moçambique. Licenciature thesis, Universidade do Algarve, Faro. 54 pp.

Alongi, D.M., Tirendi, F. \& Clough, B.F. (2000). Below-ground decomposition of organic matter in forests of the mangroves Rhizophora stylosa and Avicennia marina along the arid coast of Western Australia. Aquat. Bot., 68: 97-122.

Amade, F.M.C. (2006). Estudo da estrutura das comunidades de mangal: Avicennia marina, Ceriops tagal e Rhizophora mucronata em três locais na baía de Maputo (Costa do Sol, Ponta Rasa e Saco da Inhaca). Licenciature thesis. Maputo, Universidade Eduardo Mondlane. $42 \mathrm{pp}$.
Ashton, E.C., Hogarth, P.J. \& Ormond, R. (1999). Breakdown of mangrove leaf litter in a managed mangrove forest in Peninsular Malaysia. Hydrobiol., 413: 77-88.

Barbosa. F.M.A., Cuambe, C. C. \& Bandeira, S.O. (2001). Status and distribution of mangroves in Mozambique. S. Afr. J. Bot., 67: 393-398.

Beentje, H. \& Bandeira, S. (2007). Field Guide to the Mangrove Trees of Africa and Madagascar. $1^{\text {st }}$ edition, Royal Botanic Gardens, Kew,91 pp.

Bosire, J.O., Dahdouh - Guebas, F., Kairo, J.G., Kazungu, J., Dehairs, F. \& Koedam, N. (2005). Litter degradation and CN dynamics in reforested mangrove plantations at Gazi Bay Kenya. Biol. Conserv., 126: 287-295.

Bosire, J.O., Dahdouh-Guebas, F., Kairo, J.G., Koedam, N. (2003). Colonization of nonplanted mangroves into reforested mangrove stands. Aquat. Bot., 76: 267-279.

Boto, K. G., Bunt, J.S. \& Wellington, J.T. (1984). Variations in mangrove forest productivity in Northern Australia and Papua New Guinea. Estuar., Coast. Shelf Sci., 19: 321-329.

Chale, F.M.M., (1996). Litter production in an Avicennia germinas stern forest in Guyana, South America. Hydrobiol., 330: 47-53.

Chapman, S.B. (1986). Production Ecology and Nutrient Budgets. In: Moore, P.D. \&. Chapman, S.B. Methods in Plant Ecology. Second Edition, Oxford, Blackwell Scientific Publications. $1-59 \mathrm{pp}$.

De Boer, W. (2000). Biomass dynamics of seagrasses and the role of mangrove and seagrass vegetation as different nutrient sources for an intertidal ecosystem. Aquat. Bot., 66: 225-239.

Dick, T.M. \& Osunkoya, O.O. (2000). Influence of tidal restriction floodgates on decomposition of mangrove litter. Aquat. Bot., 68: 273-280.

Ellis, W.L. \& Bell, S.S. (2004). Canopy gaps formed by mangrove trimming: an experimental test of impact on litter fall and standing litter stock in southwest Florida (USA). J. Exp. Mar. Biol. Ecol., 311: 201-222.

Ellison, A.M. \& Farnsworth, E.J. (1997). Simulated sea level change alters anatomy, physiology, growth, and reproduction of red mangrove (Rhizophora mangle L.). Oecol. 112: 435-446. 
Guerreiro, J., Freitas, S., Pereira, P., Paula, J. \& Macia jr, A. (1996). Sediment macrobenthos of mangrove flats at Inhaca Island, Mozambique. Cah. Biol. Mar., 37: 309- 327.

Hegazy, A.K. (1998). Perspectives on survival, phenology, litter fall and decomposition, and caloric content of Avicennia marina in the Arabian Gulf region. J. Arid Environ., 40: 417-429.

Hogarth, P.J. (1999). The Biology of Mangroves. New York, University Inc. Press. 228 pp.

Kalk, M., (1995). A Natural History of Inhaca Island Mozambique. Third edition, Cape Town, Witwatersrand University Press. 395 pp.

Mall, L. P., Singh, V. P., Garge, A. (1991). Study of biomass, litter fall, litter decomposition and soil respiration in monogeneric mangrove and mixed mangrove forest of Andaman Islands. Trop. Ecol., 32: 144-152.

Morrisey, D., Beard, C., Morrison, M. Craggs, R, \& Lowe, M. (2007). The New Zealand Mangrove: Review of the Current State Of Knowledge. Auckland Regional Council Technical Publication Number 325.

Mundlovo, S. (2006). Tabela de Marés 2007. Instituto Nacional de Hidrografia e Navegação. 85 pp.

Nybakken, J.W. (1993). Marine Biology, An Ecological Approach. Third edition, New York, Harper Collins College Publishers. 462 pp.

Raffaelli, D. \& Hawkins, S. (1996). Intertidal Ecology. $1^{\text {st }}$ edition,. Londres, Chapman and Hall. 356 pp

Robertson, A.I. (1988). Decomposition of mangrove leaf litter in tropical Australia. $J$. Exp. Mar. Biol. and Ecol., 116: 235-247.

Saket, M. \& Matusse, R. (1994). Study for the deterioration of the rate of deforestation of the mangrove vegetation in Mozambique. DNFFB. Maputo. 9 pp.

Simango, A.T. (2007). Impacto de pH, temperature, salinidade e teor de nutrients na distribuição da espécie de Avicennia marina no mangal da Costa do Sol. Licenciature thesis. Maputo, Universidade Eduardo Mondlane. 31 pp.
Shunula, J.P. \& Whittck, A. (2001). A role of leaf litter degradation, and nitrogen and carbon release in species from three families of mangroves in Zanzibar. In: Richmond M. D. \& Francis J. (edrs) Marine Science Development in Tanzania and Eastern Africa. Proceeding of the $20^{\text {th }}$ Anniversary conference on Advances in Marine Science in Tanzania. 28 June - 1 July 1999, Zanzibar, Tanzania. IMS WIOMSA 565 pp.

Tam, N.F.Y., Vrijmoed, L. \& Wong, Y.S. (1990), Nutrient dynamics associated with leaf decomposition in a small subtropical mangrove community in Hong Kong. Bull. Mar. Sci., 47: 68-78

Tam, N.F.Y., Wong, Y.S., Lan, C.Y. \& Wang, L.N. (1998). Litter production and decomposition in a subtropical mangrove swamp receiving wastewater. J. Exp. Mar. Biol. Ecol., 226: 1-18.

Twilley, R.R. (1985). The exchange of organic carbon in basin mangrove forest in a southwest Florida estuary. Estuar. Coast. Shelf Sci., 20: 543-557.

Underwood, A.J. (1997). Experiments in Ecology. Their Logical Design and Interpretation Using Analysis of Variance. Cambridge Univ. Press, Cambridge. 504 pp.

Van Der Valk, A. G. \& Attiwill, P. M. (1984). Decomposition of leaf and root litter of Avicennia marina at Westernport Bay, Victoria, Australia. Aquat. Bot., 18: 205-221.

Wafar, S., Untawale, A.G. \& Wafar, M. (1997). Litter fall and energy flux in a mangrove ecosystem. Estuar. Coast. Shelf Sci., 44: 111-124.

Woodroffe, C.D. (1985). Studies of a mangrove basin, Tuff Crater, New Zealand: I. mangrove biomass and production of detritus. Estuar. Coast. Shelf Sci., 20: 265-280.

Woodroffe, C. D., Bardsley, K. N., Ward, P. J. \& Hanley J. R. (1988). Production of Mangrove litter in a macrotidal embayment, Darwin Harbour, N. T., Australia. Estuar. Coast. Shelf Sci., 26: 581-598.

Yong Ye, N. F. Tam, C.-Y. L. \& Wong, Y. (2005). Effects of salinity on germination, seedling growth and physiology of three salt-secreting mangrove species. Aquat. Bot., 85: 193-205. 